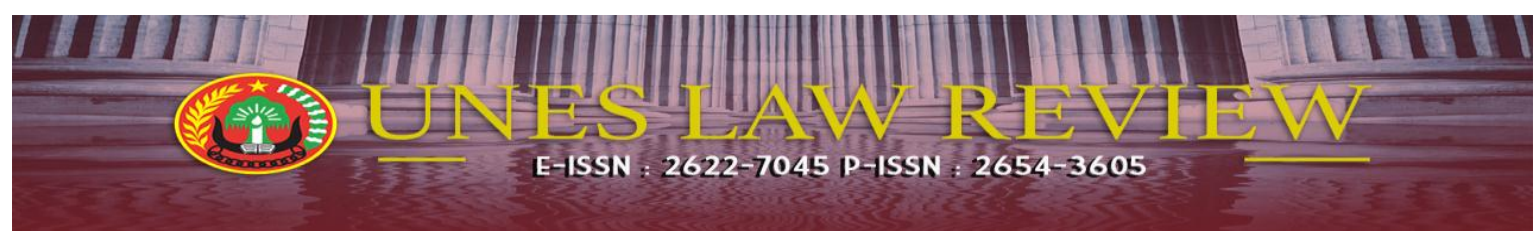

Email : uneslawreview@gmail.com Online : http://review-unes.com/index.php/law/index

Volume 1, Issue 3, Maret, 2019

E-ISSN : 2622-7045

P-ISSN : 2654-3605

\title{
ANALISIS KRIMINOLOGI TINDAK PIDANA PENIPUAN OLEH ANGGOTA POLRI DI POLRES SOLOK SELATAN
}

\author{
Henwel \\ Program Magister Ilmu Hukum, Universitas Ekasakti \\ Email: andriananugrah07@gmail.com
}

\begin{abstract}
In committing a crime of fraud, of course, a perpetrator must have tactics or methods used in carrying out the action, because this is done by the deceiver so that his goal to cheat can be achieved. Associated with fraudulent crimes that occur in South Solok can not be separated from various factors that encourage the perpetrators to do these actions, ranging from economic, social motives and may even be driven by evil instincts that exist in my servants. Every criminal act committed is closely related to the character and character of a criminal.
\end{abstract}

keywords: Kriminologi, Tindak Pidana Penipuan

\section{PENDAHULUAN}

Dalam KUHP, penipuan ini diatur dalam buku II Titel XXV Pasal 370 sampai dengan Pasal 395, yang mencangkup penipuan dalam arti sempit (Oplichting) dan penipuan dalam arti luas (bedrog).Jika diperhatikan bunyi Pasal 378 KUHP, tergambar bahwa unsur penting dari penipuan itu adalah "membujuk" orang dengan "tipu muslihat" untuk memberikan sesuatu barang atau uang. Dan pada prinsipnya untuk mempermudah pelaksanaan oleh penipu untuk mencapai sasaran dari kejahatan tersebut, berhubungan juga dengan hal-hal lain yang dapat dimanfaatkan yaitu, membujuk, nama palsu, keadaan palsu, akal cerdik, dan karangan perkataan bohong. Dalam arti lain penipuan juga meliputi perbuatan-perbuatan yang diwujudkan dengan segala tindakan yang licik dengan maksud jahat yang dilakukan untuk menimbulkan kerugian atas harta benda orang lain dan juga harta benda badan hukum.

Jadi dengan demikian jelaslah bahwa sifat hakekat dari kejahatan penipuan ini adalah dengan maksud untuk menguntungkan diri sendiri atau orang lain secara tidak sah atau melawan hukum dan hak, dengan menggerakkan orang lain untuk menyerahkan 
atau berbuat dengan mempergunakan upayaupaya penipuan seperti yang disebut secara eksplisit dalam Pasal 378 KUHP di atas.Dalam melakukan tindak pidana penipuan tentunya seorang pelaku harus mempunyai siasat atau cara-cara yang dipergunakan dalam melakukan aksinya, karena hal ini dilakukan oleh si penipu agar tujuannya untuk menipu dapat tercapai. Menurut H. A. K. Moch. Anwar ada 4 cara yang bisa dilakukan oleh sipenipu dalam melakukan penipuan ${ }^{1}$ :

1. Nama palsu

2. Keadaan atau sifat palsu

3. Rangkaian kata-kata kebohongan

4. Tipu muslihat

Terkait dengan tindak pidana penipuan yang terjadi di Solok Selatan tidak terlepas dari berbagai factor penyebab yang mendorong pelaku melakukan perbuatan tersebut, mulai dari motif ekonomi, sosial dan bahkan bisa jadi didorong oleh naluri jahat yang ada pada diri sipelaku. Setiap perbuatan pidana yang dilakukan sangat erat hubungannya dengan karkater dan watak seorang pelaku kejahatan.Demikian halnya dengan kasus yang penulis lakukan penelitian, pelaku penipuan adalah seorang anggota Polri atau penegak hukum yang disangkakan telah melanggar ketentuan Pasal 378 KUHP. Dimana tersangka meminta uang korbannya sebesar Rp. 45.000 .000 (empat puluh lima juta

1 H. A. K. Moch. Anwar, Hukum Pidana Bagian Khusus (KUHP Buku II) Jilid I, PT. Citra Aditya Bakti, Bandung, 1994, hlm 41-42. rupiah) dan korbannya dijanjikan lulus ujian CPNS kategori II, dengan kesepakatan jika korban tidak lulus maka uang korban akan dikembalikan lagi oleh tersangka.

Berdasarkan uraian di atas, maka menjadi penting penelitian ini dilakukan karena pelakunya adalah seorang aparat penegak hukum, yang seharusnya menjunjung tinggi nilai-nilai kaedah hukum. Disamping itu, jika pelakunya adalah seorang pengangguran mungkin motif ekonomi menjadi alasan utama kenapa dia melakukan penipuan, tetapi bagi seorang anggota Polri yang melakukan tindak pidana penipuan dengan alasan motif ekonomi sebagai penyebab sulit untuk diterima akal sehat kecuali karena ketamakan dan motif yang lebih spesifik lagi.

\section{HASIL DAN PEMBAHASAN}

Tindak Pidana Penipuan yang Dilakukan Oleh Anggota Kepolisian Polres Solok Selatan

Perbuatan pidana dapat saja menjerat semua orang tanpa memandang status sosial, jabatan atau jenis kelamin, akan tetapi yang membedakannya adalah faktor yang mendorong seseorang tersebut melakukan tindak pidana penipuan. Faktor pendorong dapat berupa motif ekonomi, gaya hidup, lingkungan dan faktor lainnya baik berasal dari internal maupun eksternal diri pelaku.

Berikut disajikan data tindak pidana penipuan uang yang dilakukan oleh anggota 
Polres Solok Selatan dalam rentang waktu tahun 2013-2017:

Tabel 1

Data Tindak Pidana Penipuan

Yang dilakukan Anggota

Polri Resort Solok Selatan

\begin{tabular}{|l|c|l|}
\hline Tahun & \multicolumn{1}{|c|}{ Pelaku } & Keterangan \\
\hline $2013-$ & AIPTU & Tindak \\
2015 & MUSMULYADI & $\begin{array}{l}\text { Pidana yang } \\
\text { dilakukan } \\
\text { badalah } \\
\end{array}$ \\
& & $\begin{array}{l}\text { Tindak } \\
\text { Pidana } \\
\text { Penipuan. }\end{array}$ \\
& & - \\
\hline 2016 & & - \\
\hline 2017 & - & - \\
\hline
\end{tabular}

Sumber: Polres Solok Selatan Tahun 2018

Berdasarkan data di atas, dapat dijelaskan bahwa jumlah anggota Polri sebagai tersangka tindak pidana penipuan tidak signifikan, namun dari statusnya sebagai anggota Polri (penegak hukum) tentunya mendapat perhatian dari banyak kalangan, terutama motif yang bersangkutan melakukan perbuatan pidana tersebut.

Kasus tersebut di atas, tersangkanya adalah seorang oknum anggota Polri yaitu Musmulyadi berpangkat Aiptu, yang bersangkutan anggota Polres Solok Selatan. Tindak pidana yang dituduhkan pada tersangka adalah tindak pidana penipuan uang dalam penerimaan CPNS Kabupaten Solok Selatan.Tindak pidana penipuan tersebut terjadi pada Bulan November 2013 bertempat di asarama polisi Polsek Sungai Pagu Kecamatan Sungai Pagu Kabupaten Solok Selatan.
Berdasarkan kejadian tersebut, korban melaporkan perbuatan tersangka ke Polres Solok Selatan.Dalam rangka membuat terang kasus tersebut telah dilakukan tindakan penyidikan. Dalam rangka mendapatkan barang bukti telah dilakukan penyitaan dengan Surat Perintah Penyitaan Nomor Pol SpSita/23/X/2014/reskrim, tanggal 13 oktober 2014, telah dilakukan tindakan hukum penyitaan terhadap barang bukti berupa 1 (satu) lembar kwitansi tanda terima uang sebesar Rp. 45.000.000,-(empat puluh lima juta rupiah) pada tanggal 7 November 2013. Penyitaan yang dilakukan kemudian dibuatkan berita acara penyitaannya dan laporan guna memperoleh persetujuan Pengadilan Negeri dengan surat No.Pol :B/108/IX/2010/reskrim, tgl. 15 September 2010 dan telah disetujui oleh Pengadilan Negeri Kab.Solok dengan surat keterangan penetapan No. 105/II.A.FL/2010/PN.KBR, tanggal 16 September 2010.

Bentuk Sanksi terhadap Anggota Polri yang Melakukan Tindak Pidana di Polres Solok Selatan

Penegakan hukum adalah proses dilakukannya upaya untuk tegaknya atau berfungsinya norma-norma hukum secara nyata sebagai pedoman perilaku dalam lalulintas atau hubungan-hubungan hukum dalam kehidupan bermasyarakat dan bernegara. Ditinjau dari sudut subyeknya, penegakan hukum itu dapat dilakukan oleh subyek yang luas dan dapat pula diartikan sebagai upaya penegakan hukum itu 
melibatkan semua subyek hukum dalam setiap hubungan hukum.

Penegakan hukum terhadap anggota kepolisian yang melakukan tindak pidana penipuan sesuai dengan peraturan perundangundangan, dimana proses hukum terhadap anggota kepolisian yang melakukan tindak pidana penadahan dilakukan berdasarkan ketentuan yang diatur dalam KUHP, KUHAP dan peraturan perundang-undangan yang mengikat bagi anggota Polri. Upaya penanggulangan terhadap tindak pidana penipuan meliputi pembinaan mental dan rohani, menekankan pada pengawasan disiplin dan pemberian sanksi disiplin terhadap anggota kepolisian,, peningkatan kesejahteraan anggota kepolisian dan menekankan pemantapan karakter dari anggota Polri. Disarankan kepada anggota kepolisian yang melakukan tindak pidana penipuan agar tidak mengulangi tindak pidana yang dilakukannya, adanya tindak lanjut dari pihak Polisi untuk meningkatkan pengawasan disiplin dan pemberian sanksi disiplin kepada anggota polisi yang melakukan tindak pidana penadahan, bagi Pengadilan agar dapat memberikan sanksi yang lebih berat kepada pelaku tindak pidana, khususnya tindak pidana penipuan.

Khusus dalam wilayah hukum Polres Solok Selatan, bagi anggota yang melakukan tindak pidana akan diberikan sanksi sesuai dengan ketentuan hukum yang berlaku. Jika anggota Polri melakukan tindak pidana maka jenis dan bentuk sanksi yang diberikan meliputi: $^{2}$

1. Sanksi pidana sesuai dengan ketentuan hukum pidana; dan

2. Sanksi disiplin, hal ini dapat berupa disiplin ringan, dan berat.

Prosedur Pemberian Sanksi Kepada Anggota Kepolisian yang Melakukan Tindak Pidana di Polres Solok Selatan

Penegakan hukum terhadap anggota

Kepolisian yang telah terbukti melakukan tindak pidana maka penyelesaian perkaranya sama dengan masyarakat pada umumnya yaitu melalui peradilan umum. Selain peradilan umum anggota polisi yang melakukan tindak pidana juga akan ada tambahan lain yaitu dari internal Kepolisian sendiri yang berupa penegakan hukum melalui sidang kode etik polisi.

Proses penegakan hukum Polisi yang melakukan tindak pidana penipuan di Polres Solok Selatan ${ }^{3}$ yaitu melalui proses peradilan umum. Sistem peradilan pidana di dalamnya terkandung gerak sistemik dari subsistem pendukungnya, yakni Kepolisian, Kejaksaan, Pengadilan, Lembaga Pemasyarkatan, yang secara keseluruhan dan merupakan suatu kesatuan (totalitas) Berusaha mentransformasikan masukan menjadi luaran yang menjadi tujuan sistem peradilan pidana yaitu, menanggulangi kejahatan atau

\footnotetext{
${ }^{2}$ Hasil wawancara penulis dengan penyidik pembantu Brigadir Rudi Ardi pada tanggal 3 Juli 2018

${ }^{3}$ Hasil wawancara penulis dengan penyidik pembantu Brigadir Rudi Ardi pada tanggal 3 Juli 2018
} 
mengendalikan terjadinya kejahatan agar berada dalam batas-batas toleransi yang dapat diterima masyarakat. Dalam suatu sistem yang baik tidak boleh terjadi suatu pertentangan atau antara bagian-bagian, dan terjadi suatu duplikasi (overlapping) di antara bagianbagian itu.

Berikut diuraikan proses penyidikan sebagai bagian dari proses peradilan umum bagi anggota Polri yang melakukan tindak pidana, dalam penelitian ini Sdr.Musmulyadi, pekerjaan Polri di Polres Solok Selatan diduga melakukan tindak pidana penipuan berdasarkan Laporan Polisi Nomor LP/108/VIII/2014/Polres. Saudara Helmizon melaporkan saudara Musmulyadi telah melakukan tindak pidana penipuan yang menjanjikan meluluskan pelapor dalam tes CPNS K2 dengan membayarkan sejumlah uang sebanyak Rp. 45.000.000 (empat puluh lima juta rupiah).

Setelah laporan diterima dari korban, Polres Solok Selatan melakukan tindakantindakan penyidikan sebagai berikut:

1. Polres Solok Selatan mengeluarkan Surat Perintah Penyidikan Nomor Sp Sidik/31/VIII/2014/Reskrim, tanggal 27 Agustus 2014.

2. Melakukan pemanggilan saksi-saksi

a. Saksi Helmizon, memberikan keterangan pada hari Rabu tanggal 27 Agustus tahun 2014 sekira pukul $10.00 \mathrm{Wib}$ b. Saksi Junaidi, memberikan keterangan pada hari Kamis tanggal 15 Agustus tahun 2014 sekira pukul 09.30 Wib.

c. Saksi Ivan Baroza, memberikan keterangan pada hari Rabu tanggal 27 Agustus tahun 2014 sekira pukul $11.05 \mathrm{Wib}$

d. Saksi Mela Oktalina, memberikan keterangan pada hari Senin tanggal 18 Agustus tahun 2014 sekira pukul 10.00 Wib.

3. Melakukan Penyitaan

4. Dalam rangka proses penyidikan telah dilakukan tindakan penyitaan dengan Surat Perintah Penyitaan No. Pol: SPSita/23/X/2014/Reskrim, tanggal 13 Oktober, telah dilakukan tindakan hukum penyitaan terhadap barang bukti berupa 1 (satu) lembar kwitansi tanda terima uang sebesar Rp. 45.000 .000 (empat puluh lima juta rupiah) yang diberikan oleg saudara Helmizon kepada Sdr Musmulyadi, pada tanggal 07 November 2013. Penyitaan yang dilakukan kemudian dibuatkan Berita Acara Penyitaannya dan laporan guna memperoleh persetujuan Pengadilan Negeri dengan Surat No. Pol: B/108/IX/2010/Reskrim, tanggal 15 September 2010, dan telah disetujui oleh Pengadilan Negeri Kabupaten Solok dengan Surat Penetapan No. 105/II.A.FL/2010/PN.KBR tanggal 16 September 2010. 
5. Selama proses penyidikan terhadap yang bersangkutan tidak dilakukan penangkapan dan penahanan.

6. Setelah penyidik mendengarkan keetrangan saksi-saksi termasuk saksi korban termasuk barang bukti, Penyidik membuat Berita Acara Pendapat (Resume) dengan kesimpulan sebagai berikut:

Berdasarkan pembahasan kasus di atas, ada petunjuk terjadinya tindak pidana penipuan yang diatur dalam Pasal 378 KUHP sebagai berikut:

"Barangsiapa dengan maksud hendak menguntungkan diri sendiri atau orang lain dengan melawan hak, baik dengan memakai nama palsu, atau keadaan palsu, baik dengan akal dan tipu muslihat, maupun dengan karangan perkataan-perkataan bohong, membujuk orang supaya memberikan suatu barang, membuat utang atau menghapuskan utang, dihukum karena penipuan dengan hukuman penjara selama-lamanya empat tahun".

Adapun hasil pemeriksaan terhadap Sdr. Musmulyadi dan saksi-saksi, terpenuhinya empat unsur dalam Pasal 378 tersebut yaitu, Berdasarkan fakta kejadian,ketrangan saksi-saksi,ketrangan tersangka sendiri dan dari analisa/pembahasan serta alibi peristiwa/perkara dapat disimpulkan bahwa atas perbuaan yang telah dilakukan oleh Musmulyadi Pgl. Mus, 37 Tahun, Suku Melayu (kerinci),Pekerjaan
Polri, alamat Asrama Polsek Sungai Pagu Kecmatan Sungai Pagu kabupaten Solok Selatan, maka terhadapnya dapat disangkakan telah melakukan Tindak Pidana Penipuan sebagaimana dimaksud dalam rumusan Pasal 378 Kitab Undang-Undang Hukum Pidana (KUHP).

Berdasarkan Surat Kapolres Solok Selatan Nomor R/58/III/2016/Reskrim pada tanggal 31 Maret 2016 telah diserahkan tersangka dan barang bukti ke Kejaksaan Negeri Padang Aro untuk dilakukan penuntutan.

Analsis Faktor Penyebab Terjadinya
Penipuan Uang Oleh Anggota Polri Di
Polres Solok Selatan Tugas polisi dalam bidang penegak hukum adalah melakukan penyelidikan dan penyidikan, dalam pemberantasan tindak pidana, polisi perlu lebih dahulu memiliki kesadaran dan mental tangguh yang tidak akan tergoyahkan oleh pengaruh dari pihak manapun dalam memberantas kejahatan. Polri atau Kepolisian Negara Republik Indonesia adalah suatu pranata umum sipil yang mengatur tata tertib dan hukum.Polri merupakan alat Negara sebagai alat penegak hukum.Yang dimana Polri dalam menjalankan tugas menegakkan hukum harus sesuai dengan undang-undang yang berlaku dan selalu memegang teguh kode etik profesi Kepolisian.

Dewasa ini institusi Kepolisian terutama dalam hal penegakan hukum mendapat banyak tantangan dan ujian, salah satunya yaitu berkenaan dengan penegakan 
hukum pada tindak pidana, dimana penyidik Kepolisian dihadapkan pada suasana dilematis yang tersangkanya adalah anggota Kepolisian.

Namun karena profesional dan kode etik maka penegakkan hukum terus dilakukan.Anggota Polri yang seharusnya sebagai alat negara penegak hukum dalam memberantas kejahtaan sangat fatal apabila terlibat langsung maupun tidak langsung melakukan tindak pidana.

Berkaitan dengan kasus yang penulis lakukan penelitian dimana tersangkanya adalah anggota Polri, maka perlu sebuah kajian ilmiah dari sudut pandang kriminologi kenapa seseorang anggota Polri melakukan kejahatan.Studi kriminologi tidak hanya terfokus dalam berbagai peristiwa kejahatan namun, cakupan studi kriminologi juga meliputi bentuk, penyebab, konsekuensi dari berbagai kejahatan, serta berbagai bentuk reaksi sosial yang diakibatkan oleh kejahatan. Termasuk reaksi sosial terhadap peraturan perundang-undangan serta berbagai kebijakan pemerintah. Oleh karena cakupan studi kriminologi yang begitu luas sehingga pusat kajiannya tidak hanya berhenti pada deskripsi tentang peristiwa dan bentuk kejahatan yang terjadi di atas permukaan tetapi, juga menelusuri penyebab atau akar kejahatan itu sendiri baik yang di sebabkan oleh individu, maupun yang bersumber dari berbagai peristiwa sosial, budaya, ekonomi termasuk berbagai kebijakan pemerintah. Bahkan juga mengkaji upaya pengendalian kejahatan serta reaksi terhadapnya baik secara formal maupun informal. Kejahatan adalah suatu nama atau cap yang diberikan orang untuk menilai perbuatan- perbuatan tertentu, sebagai perbuatan jahat. Dengan demikian maka si pelaku disebut sebagai penjahat.

\section{Upaya Penanggulangan Tindak Pidana Penipuan Uang Oleh Anggota Polri Di Polres Solok Selatan}

Secara umum upaya penaggulangan dan pencegahan dilakukan oleh institusi Polri terhadap anggota Polri yang melakukan tidak pidana meliputi:

1. Pembinaan merupakan salah satu upaya antisipasi cegah dini yang dilakukan oleh Polri melalui kegiatan-kegiatan dengan tujuan menghilangkan alasan peluang dan pendorong Anggota Polri melakukan kejahatan atau tindak pidana.Tujuan dilaksakannya kegiatan ini untuk menghilangkan faktor peluang dan pendorong terkontaminasinya seseorang menjadi pelaku kejahatan serta menciptakan daya tangkal dan memotivasi membangkitkan kesadaran anggota Polri agar tidak melakukan Tindak Pidana. Contoh langkah yang di ambil ialah oleh Kepolisian Resort Solok Selatan adalah memberikan penyuluhan agama agar setiap anggotanya memiliki iman yang kuat dan tidak melanggar norma Agama, penyuluhan ini dilakukan minimal 1 kali dalam sebulan.

2. Preventif Merupakan tindakan lanjut yang dilakukan untuk mencegah terjadinya 
Tindak Pidana penipuan melalui pengendalian dan pengawasan terhadap tiap-tiap anggotanya.Langkah ini bentuknya adalah:

a) Melakukan kontrol dan kerjasama antar sesama anggota Polri untuk mengawasi dan saling mengingatkan saat adanya kegiatan yang berpotensi terjadinya tindak kejahatan, termasuk tindak pidana penipuan.

b) Melakukan pembinaan secara kontinyu dan melekat oleh atasan langsung; Contoh atasan langsung sewaktu-waktu dapat mengontrol dan menanyakan keberadaan anggotanya.

3. Represif merupakan upaya terakhir dalam memberantas tindak pidana penipuan, yaitu dengan cara melakukan penindakan terhadap anggta Polri orang yang diduga melakukan tindak kejahatan baik karena dilaporkan maupun tindak pidana lain yang dapar merubak harkat dan martabat ogansiasi Polri. Langkah represif inilah yang dilakukan kepada setiap anggota Polri yang melakukan tindak pidana, termasuk tindak pidana penipuan sebagai tindakan tegas dan konsisten sehingga membuat jera setiap anggota Polri serta memberikan prevensi umum kepada anggota Polri lainnya.

Kendala-Kendala dalam Penanggulangan Tindak Pidana Penipuan Uang Oleh Anggota Polri Di Polres Solok Selatan.

Salah satu kendala atau hambatan itu adalah prilaku individu atau sekelompok individu yang menyimpang dari norma-norma yang berlaku dalam masyarakat, baik norma yang tidak tertulis seperti norma kesusilaan, kesopanan, adat istiadat, agama maupun dalam konteks ini terutama norma hukum pidana yang sifatnya tertulis yang /leh masyarakat disebut sebagai kejahatan. Kejahatan yang terjadi tentu saja menimbulkan kerugian-kerqgian baik kerugian yang bersifat ekonomis materil maupun yajg bersifat immatepi yang menyangkut rasa aman dan tenteram dalam kehidupan bermasyarakat.Secara tegas dapat dikatakan bahwa kejahatan merupakan dingkah laku yang anti sosial (a-sosial).

Kemudian kendala umum lainnya adalah penafsiran dalam undang-undang dan berbagai hambatan baik berupa sarana fasilitas, partisipasi masyarakat, serta koordinasi antara penegak hukum masih perlu untuk dilakukan peningkatan dan optimalisasi. Namun yang pasti, sanksi harus diselesaikan secara matang agar penegakan hukum terhadap polisi yang melakukan tindak pidana dapat diselesaikan dengan sebaik mungkin dan dapat mencegah apabila terdapat polisi yang akan melakukan tindak pidana. Jadi polisi sebagai penegak hukum khususnya penegak hukum mendapatkan kepercayaan dari masyarakat dan tidak ada polisi yang melakukan tindak pidana yang tidak diproses secara hukum. 


\section{PENUTUP}

Faktor penyebab terjadinya tindak pidana penipuan oleh anggota Polri di Polres Solok Selatan adalah karena beberapa faktor antara lain faktor keinginan,faktor kesempatan, faktor gaya hidup dan faktor keluarga. Faktor tersebut diatas sesuai dengan The Multiple Theory, bahwakejahatan disebabkan oleh banyak fakor. Dari aspek mazhab Lingkungan relevan jika faktor keinginan (faktor internal) diri pelaku sebagai faktor pendorong yang bersangkutan melakukan kejahatan penipuan, demikian juga halnya dengan mazhab agama yang lebih menekankan pada rohani seseorang, jika nilainilai agama seseorang kuat dalam dirinya maka kecil kemungkinan yang bersangkutan melakukan tindak kejahatan karena fakator gaya hidup yang tidak sesuai dengan nilainilai agama itu sendiri. Upaya penanggulangan tindak pidana penipuan uang oleh anggota Polri di Polres Solok Selatan meliputi upaya Pre-emtif (Pembinaan), Pembinaan merupakan salah satu upaya antisipasi cegah dini yang dilakukan oleh Polri dengan memotivasi membangkitkan kesadaran anggota Polri berupa penyuluhan agama. Selanjutnya upaya Preventif, merupakan tindakan lanjut yang dilakukan untuk mencegah terjadinya Tindak Pidana penipuan melalui kontrol dan kerjasama antar sesama anggota Polri serta melakukan pembinaan secara kontinyu dan melekat oleh atasan langsung. Kemudian upaya Represif
(Penindakan) merupakan upaya terakhir dalam memberantas tindak pidana penipuan, yaitu dengan cara melakukan penindakan terhadap anggta Polri orang yang diduga melakukan tindak kejahatan baik melalui instrumen hukum pidana maupun tindakan hukuman disiplin. Kendala yang ditemui adalah tidak semua anggota Polri menyadari bahwa tugas-tugas yang diembanya adalah tugas penegakan hukum (Pre-emtif Pembinaan), kemudian dalam penegakan hukum dimana polisi sebagai pelaku tindak pidana adalah sesuatu hal sulit dalam artian hubungan emosioanal institusi serta kendala dalam penindakan (represif), yaitudalam proses penyidikan anggota Polri tersebut juga sudah mengetahui taktik dan teknik penyidikan.

\section{DAFTAR PUSTAKA}

\section{Buku}

H. A. K. Moch. Anwar, Hukum Pidana Bagian Khusus (KUHP Buku II) Jilid I, PT. Citra Aditya Bakti, Bandung, 1994.

Hamzah Hatrik, Asas Pertanggungjawaban Korporasi Dalam Hukum Pidana Indonesia, Raja Grafindo, Jakarta, 1996.

Indah Sri Utari, Aliran dan Teori dalam Kriminologi, Thafa Media, Semarang, 2012

Jimly Asshiddiqie, Disampaikan pada acara Seminar "Menyoal Moral Penegak Hukum" dalam rangka Lustrum XI Fakultas Hukum Universitas Gadjah Mada.17 Februari 2006. 
Kanter-Sianturi, Azas-azas Hukum Pidana di Indonesia Jakarta, Alumni PTHM, 1982.

Leden Marpaung, Asas-Teori-Praktek Hukum Pidana,Sinar Grafika, Jakarta, 2009.

Mardjono Reksodiputro, Bunga Rampai Permasalahan Dalam Sistem Peradilan Pidana, Pusat Pelayanan Keadilan Dan Pengabdian Hukum, Jakarta, 1997.

Moch. Anwar, Hukum Pidana Bagian Khusus (KUHP II), Percetakan Offset Alumni, Bandung, 1979.

Moeljatno, Azas-azas Hukum Pidana, Bina Aksara, Jakarta, 1984 .

Muhammad Ali, Kamus Lengkap Bahasa Indonesia Medern, Pustaka Amani, Jakarta, 1986.

Muladi, Kapita Selekta Sistem Peradilan Pidana, Badan Penerbit UNDIP, Semarang, 1995.

Muladi dan Barda Nawawi, Bunga Rampai Hukum Pidana, Alumni, Bandung, 1992.

Zulkarnain dan Teguh Meinanda, Tanya Jawab Pengantar Ilmu Hukum, Armico, Bandung, 1981.

\section{Peranturan Undang-Undang}

Undang-Undang Nomor 1 Tahun 1946 tentang Peraturan Hukum Pidana (KUHP)

Undang-Undang Nomor 8 Tahun 1981 tentang Hukum Acara Pidana (KUHAP).
Undang-Undang Nomor 2 Tahun 2002 tentang Kepolsian Negara Republik Indonesia.

Undang - undang Nomor 3 Tahun 2009 tentang Mahkamah Agung.

Undang - Undang Nomor 48Tahun 2009 tentang Kekuasaan Kehakiman.

Undang - undang Nomor 16 Tahun 2004 tentang Kejaksaan RI.

Undang - undang Nomor 49 Tahun 2009 tentang Peradilan Umum.

Peraturan Pemerintah Nomor 58 Tahun 2010 tentang Perubahan Atas Peraturan Pemerintah Nomor 27 Tahun 1983. 